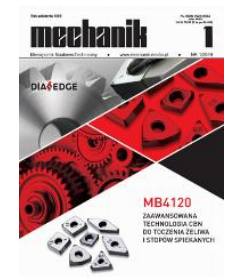

How to cite this article:

Author: Marcin Paprocki

Title of article: „Contemporary trends in the design and management of product development”

Mechanik, No. 1 (2019)

DOI: https://doi.org/10.17814/mechanik.2019.1.14

\title{
Contemporary trends in the design and management of product development
}

\section{MARCIN PAPROCKI *}

* Dr inż. Marcin Paprocki, paprockm@uek.krakow.pl, https://orcid.org/0000-0001-7282-5421 - Katedra Technologii i Ekologii Wyrobów, Uniwersytet Ekonomiczny w Krakowie, Kraków, Polska

Discussed are contemporary trends in the design, manufacturing and management of product development, including those connected with the Industry 4.0. The development strategies of a new product in terms of market, product, technology are also presented. Tools and methods aiding the proecological design and assessment of sustainable product development are described. As an example of product development modelling, models of the plastic cups production stages using the injection method before and after the identification of "hidden factories" are described.

KEYWORDS: DFE, design for environment, product development management, hidden factories, Industry 4.0

\section{(New) product development strategies}

As part of new product development strategies, we can distinguish concurrent engineering (CE) and cross enterprise engineering (CEE). At the same time, enterprises adopt and implement various development strategies for a new product to achieve market success. In this context, new product strategies can be considered in terms of market-product-technology, i.e. proactive and reactive variants.

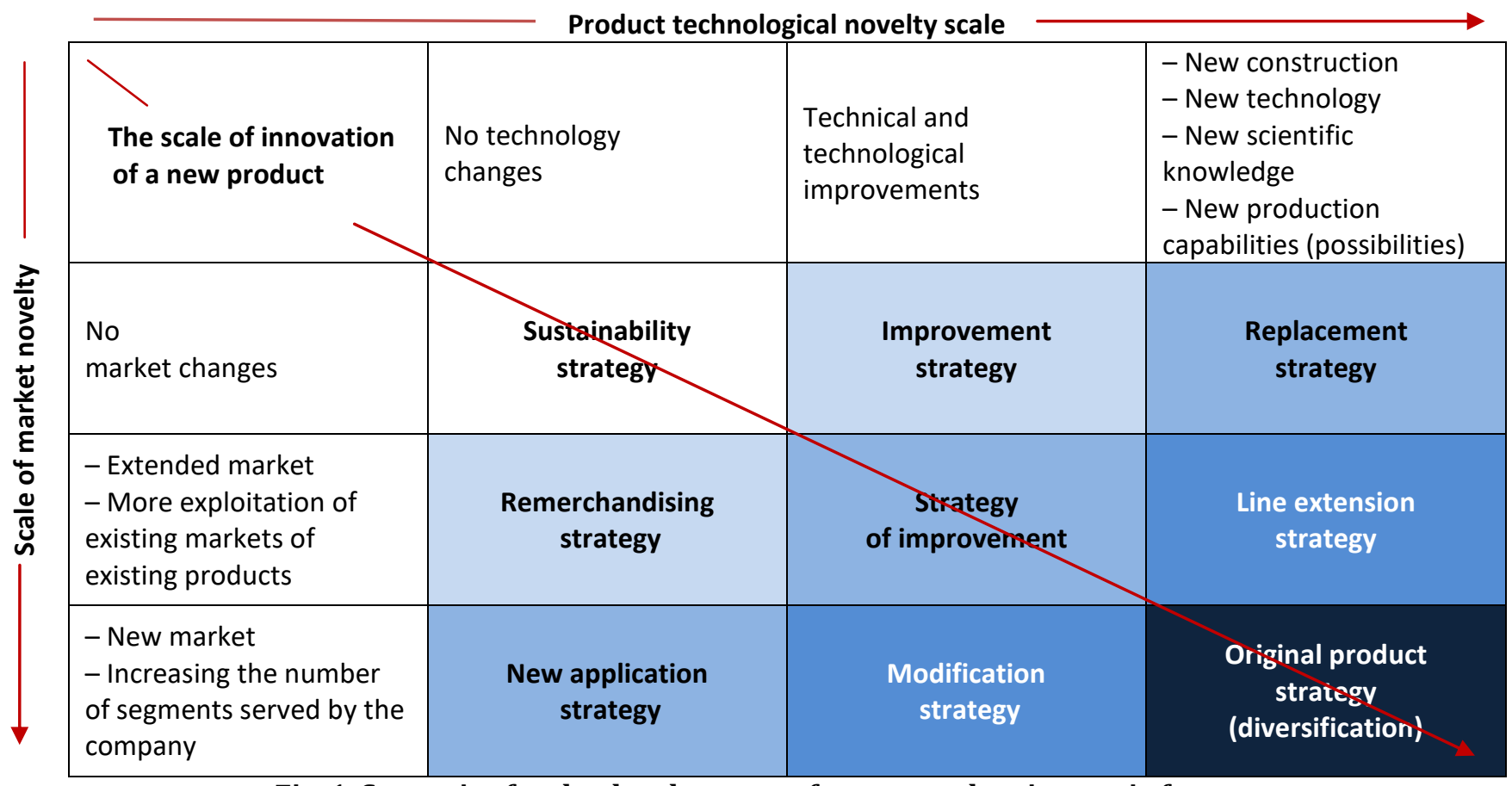

Fig. 1. Strategies for the development of a new product in matrix form according to C. Johnson and C. Jones (own study based on [2]) 
Proactive strategies for the development of a new product are characterized by activities in the field of creating product innovation and implementation of the marketing strategy. Their goal is to maintain or gain an advantage on the market.

Reactive development strategies for a new product are defensive. Their goal is to maintain market position by keeping pace with changes and the best solutions of competition. Variants that largely determine the success of a new product can be identified as part of both proactive and reactive strategies.

An example of a proactive product development strategy in which the success rate is $70 \%$ is the development of a better product without using synergy effects based on marketing knowledge and production technologies used [1].

In the field of reactive strategies, the best option is a higher quality strategy - "second but better" - with a success rate of $72 \%[2]$.

The new product development strategies included in the matrix, taking into account the scale of the technological novelty of the product and the scale of the novelty of the market, are presented in fig. 1. The discussed matrix determines the scale of product innovation (from a new one in which there are no changes, to the most innovative product - created in the result of the diversification strategy).

\section{Tools and methods supporting pro-ecological design and assessment of sustainable product development}

DFE (design for environment) is oriented towards maximum reduction of the negative impact of product development and the product itself on the natural environment $[3,4]$.

The DFE elements include design-oriented methodology: easy disassembly (DFD - design for disassembly), easy recycling (DFR - design for recycling), regeneration (DFR - design for remanufacturing), product life expectancy (DFL - design for longevity) and packaging (DFP - design for packaging).

Tools that can also support pro-ecological product design include the QFD, FMEA, DFMA and DOE methods.

QFD (quality function deployment) is a method of developing the product quality function. It allows both to design the quality of new products and to improve the quality of existing products, with particular emphasis on customer needs and requirements.

FMEA (failure mode and effects analysis) allows to predict the probability of errors, assess their effects, and then determine the reasons for their occurrence. On this basis, preventive, leveling and corrective actions can be developed that eliminate errors or minimize the likelihood of their occurrence during the design, production and use of the product.

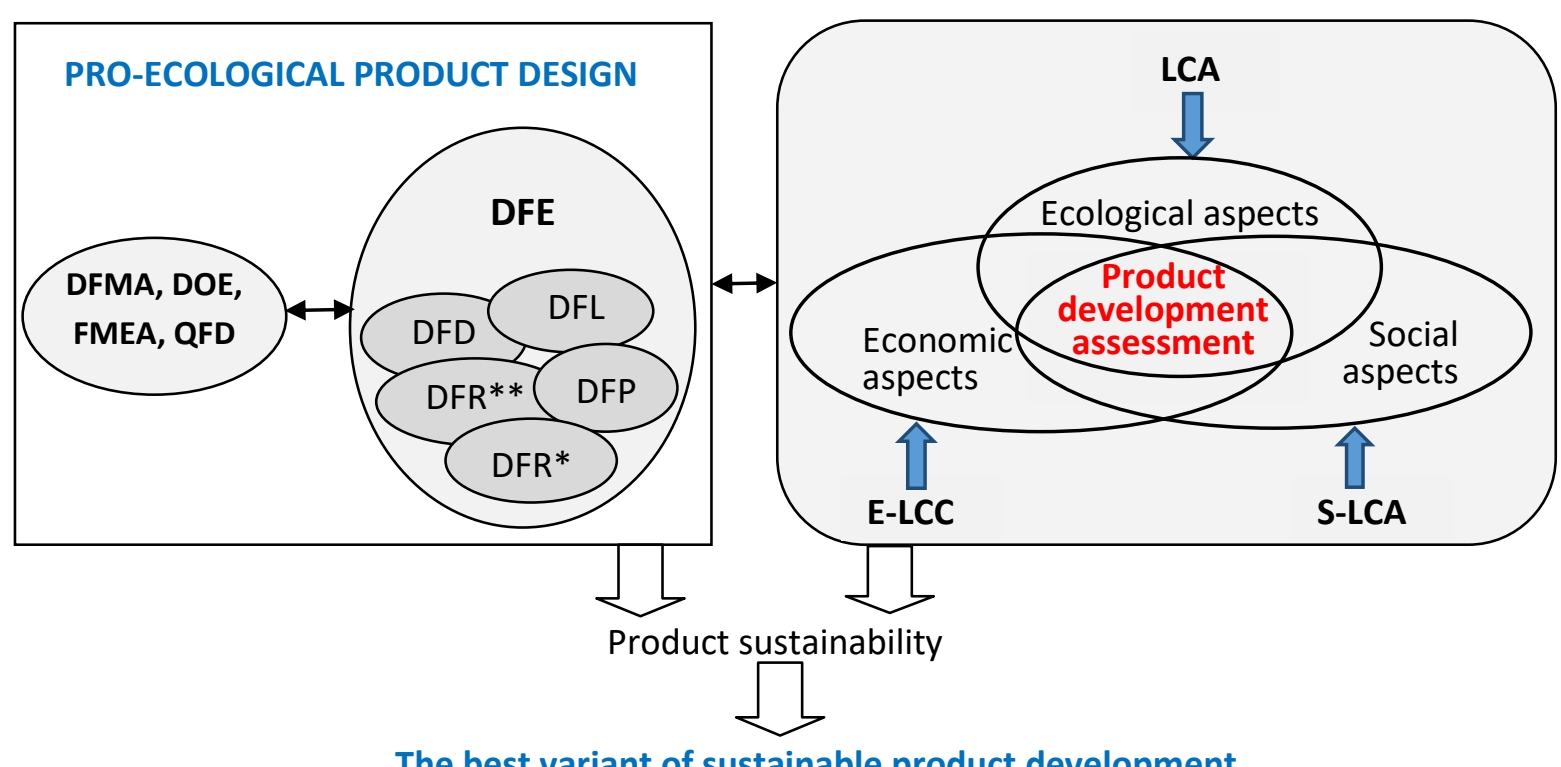

The best variant of sustainable product development

Fig. 2. Tools and methods supporting pro-ecological design of sustainable product development

The DFMA method (design for manufacture and assembly) is based on systems supporting the assessment of the solution (design and technology of the product) due to assembly and the method of production. DFMA enables, among others reducing the cost of assembling the product and the total cost of manufacturing parts by simplifying the design, as well as choosing the most effective technologies. 
The goal of DOE (design of experiments) is to obtain the largest possible amount of valuable and reliable information about the tested object, product or process with the least number of experiments [5].

The product life cycle analysis may include ecological, social and financial aspects. Ecological aspects are assessed using LCA (life cycle assessment), economic aspects - using environmental E-LCC (environmental live cycle costing), and social aspects - using S-LCA (social life cycle assessment).

The use of tools and methods of pro-ecological design and assessment of the product life cycle favors creating a sustainable product development model. This translates into the possibility of choosing the best variant of a sustainable product development (fig. 2). Product balancing may also apply to other features, such as price, quality, development strategy and legal aspects.

\section{Strategic project support for product development in a distributed environment}

Strategic project support provides the basis for effective management of product development in accordance with the assumptions of CE and CEE. It also enables the organization of enterprises in a distributed environment in the form of extended, virtual and fractal enterprises [6].

In connection with the growing importance of pro-ecological product development, it was proposed to supplement strategic support for enterprises with a component of environmental backbone assessment (ecological backbone) supported by LCA [7]. Thus, this concept can be presented as crossing components:

- product development management - supported by PLM (product lifecycle management) systems,

- enterprise resource planning - supported by the ERP system,

- management of cooperation with clients - supported by the CRM system (customer relationship management),

- management of cooperation with suppliers - supported by the SCM system (supply chain management),

- assessment of product life cycle environmental performance - assisted by LCA.

\section{Aspects of Industry 4.0 in the context of product design and development}

Trends and solutions in the spirit of the fourth industrial revolution regarding product design and development include: digital factories (DF), communication between machines (M2M), virtual reality (VR), augmented reality (AR), the internet of all things (IoT), autonomous robots and machine tools, intelligent factories and products, and cloud computing.

Implementation of Industry 4.0 solutions are favored by modern trends and methods of production, as well as the development of the Internet, artificial intelligence, IT solutions and telecommunications technologies. It seems that aspects related to the circular economy - CE as well as ecological design and sustainable product development will be important components of Industry 4.0 (fig. 3).

\section{Modern manufacturing trends}

( $R E$, incremental manufacturing methods, RP/RT, RM, erosion machining, hybrid machining, ESP, CIM, automation and robotization of production processes)

Industry 4.0

digital factories (DF), communication between machines (M2M), virtual reality (VR), augmented reality (AR), Internet of things, autonomous robots and machine to ols, smart factories and products, computing cloud

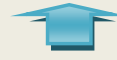

Circular economy, ecological and social aspects

(eco design, organic products, sustainable product development)
Development of the Internet, artificial intelligence, IT solutions and telecommunications technologies

Fig. 3. Aspects of Industry 4.0 in the context of product design and development

\section{Modeling of product development stages to improve the process quality - Six Sigma concept}

One of the methods of quality assurance and process and product improvement is the Six Sigma method. To achieve these goals, you can also use, among others concepts: TQM (total quality management), lean manufacturing and lean Six Sigma. 
One of the main assumptions of Six Sigma is that high quality is not an end in itself. High quality (expressed by the sigma parameter) is a tool for achieving financial success. In other management and quality improvement systems, e.g. TQM, there is often an emphasis on improving the quality of processes, services or products, without correlating this goal with achieving tangible financial benefits. For this reason, despite the increase in quality, companies do not improve the financial result, and it even deteriorates.

Modeling and simulation tools as well as conducting an experiment can help in choosing the best product development variant. They enable, among others analyzing existing and planned stages of product development in terms of quality assurance and process and product improvement. As an example, modeling of plastic cup production stages with the injection method is presented to identify "hidden factories" a significant reason for the real (low) quality of processes and products according to the Six Sigma concept.

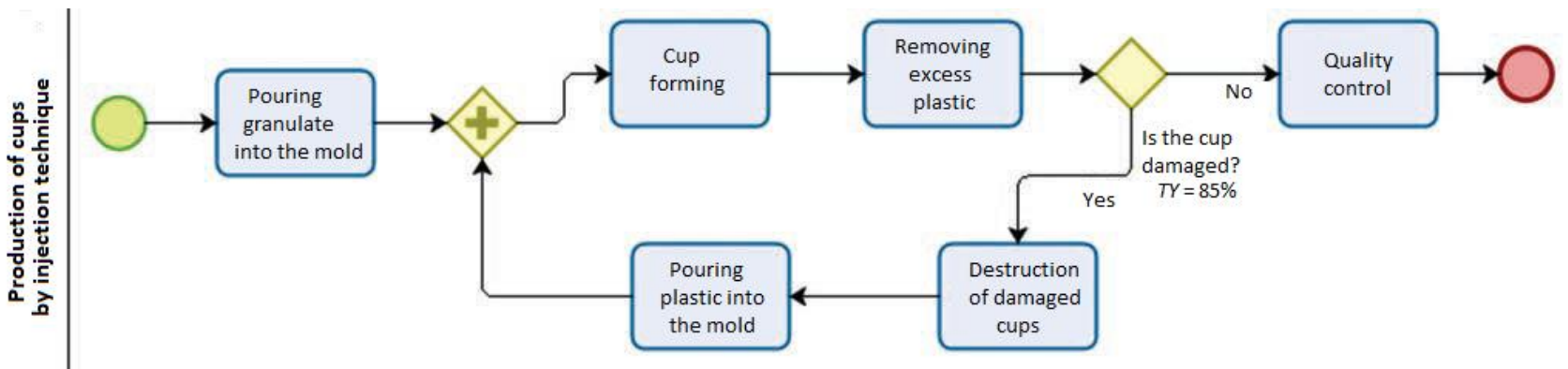

Fig. 4. Production of plastic cups by injection method before identification of "hidden factories" - Bizagi

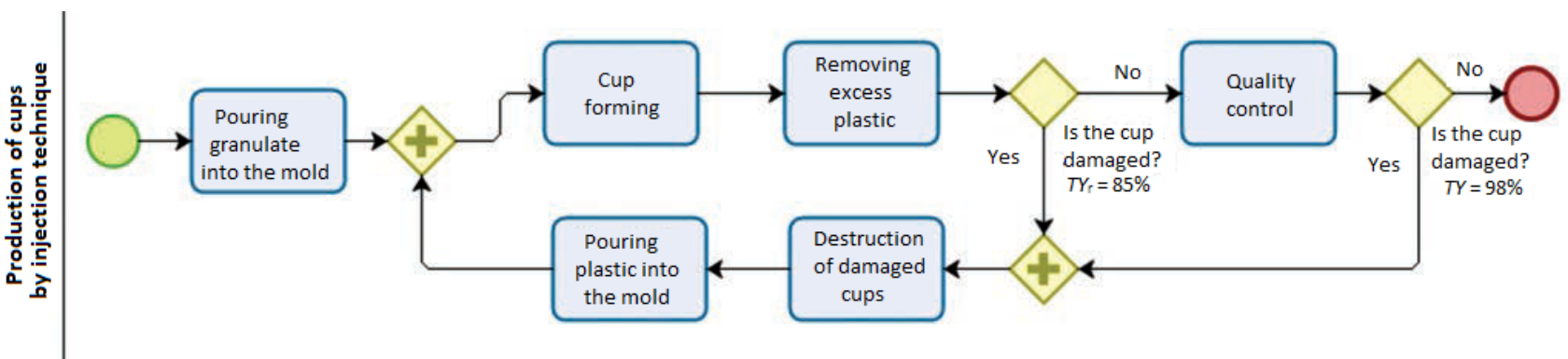

Fig. 5. Production of plastic cups by injection method after identification of "hidden factories" - Bizagi

These stages were developed based on [8]. Modeling of plastic cup production by injection method before identification (fig. 4) and after identification (fig. 5) of "hidden factories" was carried out in the Bizagi program, using BPMN notation. To determine the quality of the process, the $T Y$ indicator (throughput yield) was used. It determines the probability of non-occurrence at a given stage of production preparation and production of potential errors.

In the first modeling step, the quality of the cup production process was determined at $T Y=98 \%$ measured at the stage of product quality control. After more thorough analysis and modeling of the process, "hidden factories" were identified. In this case, they consisted of the employee destroying damaged cups to hide the poor quality of the process from the stage of its control. The actual quality of the process was $T Y_{\mathrm{r}}=85 \%$.

After identifying "hidden factories" - places of low quality - one can perform the procedure:

- improving the process quality according to the DMAIC methodology (define - measure - analyze improve - control/supervise),

- redesigning the process according to the DFSS methodology (design for Six Sigma) to obtain a $6 \sigma$ quality level.

\section{Summary}

Contemporary trends related to product design and management are discussed. Methods and tools such as DFE, DFD, DFR, DFMA, FMEA, QFD and DOE, supporting pro-ecological product development design, were presented. Using these tools and methods, as well as methods supporting the assessment of sustainable product development (LCA, E-LCC and S-LCA), one can manage product development by choosing the best option that will be a compromise between the economic criterion and the ecological and social criterion. Product balancing may also apply to other features, such as price, quality, development strategy and legal aspects. Taking into account the increase in the importance of pro-ecological product development, strategic support for enterprises has been supplemented with an ecological backbone assessment component of the product, supported by LCA. 
Modeling of product development processes using BPMN notation can facilitate the revealing of "hidden factories", i.e. actions to hide low-quality processes, according to the concept of Six Sigma. This provides the basis for improving the quality of the process according to the DMAIC methodology or redesigning the process according to the DFSS methodology.

Trends related to the development of products under the fourth industrial revolution - "Industry 4.0" - are favored, among others, by modern production methods, the development of the internet, artificial intelligence and IT solutions, as well as manufacturing technologies. It seems that aspects related to ecological design, sustainable product development as well as the circular economy will be important components of the fourth industrial revolution.

\section{REFERENCES}

[1] Urban G.L., Hauser J.R. „Design and Marketing of New Products”. Englewood Cliffs, NJ: Prentice Hall, 1993.

[2] Rutkowski I.P. „Rozwój nowego produktu. Metody i uwarunkowania”. Warszawa: PWE, 2007.

[3] Krumenauer F.Z., Matayoshi C.T., da Silva I.B. et al. „Concurrent engineering and DFMA approaches on the development of automotive panels and doors”. Journal of Achievements in Materials and Manufacturing Engineering. 31, 2 (2008): 690-698.

[4] Telenko C., Seepersad C.C., Webber M.E. „A Compilation of Design for Environment Principles and Guidelines". Proceedings of IDETC/CIE. New York, USA (2008): 1-13.

[5] Hamrol A., Mantura W. „Zarządzanie jakościq - teoria i praktyka”. Warszawa: Wydawnictwo Naukowe PWN, 2002.

[6] Paprocki M. „Aspekty rozwoju wyrobu i organizacji przedsiębiorstw w środowisku rozproszonym”. Innowacje $w$ zarzqdzaniu i inżynierii produkcji. R. Knosala [ed.]. Opole: Oficyn. Wydaw. Polskiego Towarzystwa Zarządzania Produkcją. 1 (2017): 76-87.

[7] Paprocki M. „Wykorzystanie metod i systemów komputerowego wspomagania do proekologicznego projektowania rozwoju wyrobu". Mechanik. 1 (2018): 73-75, https://doi.org/10.17814/mechanik.2018.1.17.

[8] Harry M., Schroeder R. „Six Sigma wykorzystanie programu jakości do poprawy wyników finansowych”. Kraków: Oficyna Ekonomiczna, 2005. 